\title{
Ploughing the deep sea floor
}

Pere Puig ${ }^{1}$, Miquel Canals ${ }^{2}$, Joan B. Company ${ }^{1}$, Jacobo Martín ${ }^{1}$, David Amblas ${ }^{2}$, Galderic Lastras ${ }^{2}$, Albert Palanques $^{1} \&$ Antoni M. Calafat ${ }^{2}$

${ }^{1}$ Marine Sciences Institute, CSIC, E-08003 Barcelona, Spain.

${ }^{2}$ CRG Marine Geosciences, University of Barcelona, E-08028 Barcelona, Spain.

Bottom trawling is a nonselective commercial fishing technique whereby heavy nets and gear are pulled along the sea floor. The direct impact of this technique on fish populations ${ }^{1,2}$ and benthic communities ${ }^{3,4}$ has received much attention, but trawling can also modify the physical properties of seafloor sediments, watersediment chemical exchanges and sediment fluxes ${ }^{5,6}$. Most of the studies addressing the physical disturbances of trawl gear on the seabed have been undertaken in coastal and shelf environments ${ }^{7,8}$, however, where the capacity of trawling to modify the seafloor morphology coexists with high-energy natural processes driving sediment erosion, transport and deposition'. Here we show that on upper continental slopes, the reworking of the deep sea floor by trawling gradually modifies the shape of the submarine landscape over large spatial scales. We found that trawling-induced sediment displacement and removal from fishing grounds causes the morphology of the deep sea floor to become smoother over time, reducing its original complexity as shown by high-resolution seafloor relief maps. Our results suggest that during the last decades following the industrialization of fishing fleets, bottom trawling has become an important driver of deep seascape evolution. Given the global dimension of this type of fishery, we anticipate that the morphology of the upper continental slope in many parts of the world's oceans could be altered by intensive bottom trawling, producing comparable effects on the deep sea floor to those generated by agricultural ploughing on emerged land.

Continental slopes are at the transition between shallow continental shelves and deep basins and are often cut by submarine canyons. They represent the steepest part of continental margins, which extend from the shelf break, usually at depths of 100$200 \mathrm{~m}$, to the upper continental rise at depths of 1,500-3,000 m. At fine spatial and temporal scales (that is, excluding tectonics), continental-slope morphological features form as a result of mechanisms governed by erosional and depositional processes ${ }^{10}$. Slope failures and sediment gravity flows ${ }^{11}$, geostrophic contour-flowing bottom 
currents $^{12}$, internal waves ${ }^{13}$ and dense shelf water cascading ${ }^{14}$ are some of the main processes shaping continental slopes.

Bottom trawling is recurrently practised in numerous continental slopes of the world's oceans (Fig. 1). Driven by technical improvements and the exhaustion of traditional fish stocks, trawling fleets have progressively expanded their activities from the continental shelf towards deeper regions ${ }^{15,16}$, where background energy levels controlling natural sedimentary processes are generally low except for infrequent, localized events ${ }^{11,14}$.

The northwestern Mediterranean continental slope is a region where deep-sea trawling has been practised for a long time. A monospecific fishery targeting blue and red deep-sea shrimp Aristeus antennatus (Risso, 1816) was active in this area as early as the 1930s (ref. 17). However, fishing effort (a measure of the amount of fishing, generally defined as the fleet capacity times days at sea) was negligible until the mid1960s, when the trawling fleet became fully industrialized. This trend notably accelerated in the $1970 \mathrm{~s}$ in terms of engine power $^{18}$ and, subsequently, of gear size, fishing depth and trawled area per haul. The slope fishing grounds in the northern Catalan margin are currently being regularly exploited by 180 large bottom trawlers (that is, each over $15 \mathrm{~m}$ in overall length) down to $800 \mathrm{~m}$ depth, with greater depths being reached occasionally (Fig. 2).

Time series observations were carried out on the flank of a trawled submarine canyon (La Fonera Canyon, Fig. 2) to measure sediment transport induced by fishing activities. Following an earlier study on sedimentary processes ${ }^{19}$, an instrumented mooring was placed at $980 \mathrm{~m}$ depth within a tributary valley on the canyon flank to capture the occurrence of trawl-induced sediment gravity flows. The new observations reveal a highly active scenario with the nearly daily occurrence of sediment transport events linked to the passage of the trawling fleet upslope of the mooring site (Fig. 3). Increases of near-bottom suspended sediment concentrations and current velocities from trawl-induced sediment gravity flows were observed repeatedly during weekdays at working hours, indicating a periodic sediment removal from fishing grounds. Such flows reached maximum downslope velocities of up to $38 \mathrm{~cm} \mathrm{~s}^{-1}$ and concentrations of up to $236 \mathrm{mg} \mathrm{l}^{-1}$ (Fig. 3; Supplementary Fig. 1a). Maximum instantaneous sediment fluxes at 4-6 $\mathrm{m}$ above the sea floor (m.a.s.f.) were $34 \mathrm{~g} \mathrm{~m}^{-2} \mathrm{~s}^{-1}$ and accounted for a cumulative transport of about 1.1 tonnes $\mathrm{m}^{-2}$ during the observational period 
(Supplementary Fig. 1b). This near-bottom transport is of the same order of magnitude as the wintertime downslope cumulative transport induced by storms and dense shelf water cascading in the nearby Cap de Creus and Lacaze-Duthiers submarine canyon heads ${ }^{14,20}$. Integrating the sediment transport from 4 to 50 m.a.s.f., a minimum of $5.4 \times 10^{3}$ tonnes of sediment is estimated to have been exported downslope through the monitored tributary valley in 136 days as a consequence of trawling activities (Supplementary Fig. 1c). These recurrent trawl-induced low-concentration sediment gravity flows only travel a few kilometres downslope from the canyon flank to the main canyon axis where they deposit their sediment load ${ }^{19}$. Consequently, after the industrialization of the fishing fleet, a twofold increase of the sediment accumulation rates occurred in the canyon axis ${ }^{18}$.

In 2007 a high-resolution multibeam bathymetry survey was conducted in La Fonera Canyon (Fig. 4). Analysis of the bathymetry data revealed a noticeable smoothing of bottom topography along the northern canyon flank at depths shallower than $800 \mathrm{~m}$ (Fig. 4a), which had been tentatively interpreted as being caused by dense shelf water cascading flowing southwards ${ }^{21}$. Canyon flank smoothing, however, was also observed locally in the southern canyon flank (Fig. 4a), away from the region potentially affected by cascading flows, challenging previous hypotheses. The fact that the lower limit of the smoothed bathymetric range coincided with the maximum trawled depths reported by the fishermen operating in the area pointed to trawling as a potential seafloor shaping agent within this depth range.

Plotting four years (2007-2010) of satellite-based navigation tracks from all large bottom trawlers operating in the area on top of the multibeam bathymetry of La Fonera Canyon revealed that navigation tracks coincided with the smoothed canyon flanks at depths shallower than $800 \mathrm{~m}$ (Fig. 4b) in a region characterized by homogeneous slopes (Fig. 4c) and low rugosity (a dimensionless measure of surface roughness) values (Supplementary Fig. 2). In contrast, untrawled canyon flank segments are dominated by a dense network of tributary valleys that progress upslope from the main canyon axis, reaching up to five orders of bifurcation ${ }^{21}$. Such complex morphology is missing in the trawled depth range and slightly below. Here the sea floor becomes smoother and only the main branches of the tributary valley networks are preserved (Fig. 4, Supplementary Fig. 3). Therefore, a causative relationship can be established between trawling-induced sediment erosion effects and the reduction of 
morphological complexity in the studied area. Contrasts between untrawled and trawled seafloor regions are also evident in sediment cores (Supplementary Fig. 4) and remote operated vehicle (ROV) footage from canyon flanks (Supplementary Fig. 5).

Considering only the satellite-based navigation tracks from 2010, we determine that an area of $41.6 \mathrm{~km}^{2}$ was affected in the northern canyon flank alone. This represents $76.3 \%$ of the canyon flank area that is shallower than $800 \mathrm{~m}$.

To provide an estimate of the volume of sediment that can be remobilized downslope by trawling activities, the integrated sediment transport during the observational period (Supplementary Fig. 1c) was converted to volume using a mean dry bulk density of $0.6 \mathrm{~g} \mathrm{~cm}^{-3}$ (Supplementary Fig. 4) and extrapolated to one year. Using a drainage basin of $4.2 \mathrm{~km}^{2}$ (about $10 \%$ of the canyon flank trawled during 2010) for the monitored tributary valley, approximately $2.4 \times 10^{-4} \mathrm{~km}^{3}$ is estimated to have been exported from this fishing ground annually. Assuming an equal sediment yield since the 1970s, following the industrialization of the trawling fleet ${ }^{18}$, a total of around $1.0 \times 10^{-2} \mathrm{~km}^{3}$ has potentially been removed from this canyon flank by bottom trawling, contributing to its morphological change. The actual volume remobilized over this period could easily be larger, taking into account that the surface sediments from the fishing ground are at present over-consolidated (Supplementary Fig. 4) and that downslope sediment fluxes in the past, when the morphology was rougher and the surface sediments unconsolidated and easier to resuspend, could have been much higher. Although the estimated annual volume is similar to the annual sediment volumes involved in canyon head failures, the total estimated volume remobilized from this canyon flank over four decades is two to five orders of magnitude smaller than the sediment volumes involved in open-slope submarine failures that occur over geological periods of time (Supplementary Table 1).

Recent studies assessing the impact of anthropogenic activities in the marine ecosystems have already highlighted the effects caused by bottom trawling, both at global scale ${ }^{22}$ and in deep-sea environments, where its spatial extent has been estimated to be an order of magnitude greater than the total extent of all other anthropogenic activities $^{23}$. Given that deep-sea bottom trawling has spread around the globe during the past decades ${ }^{4,15,16}$ (Fig. 1), the present study raises questions over whether bottom trawling is becoming an important driver of the upper continental slope seascape evolution during the Anthropocene ${ }^{24}$, at a scale that has been previously unnoticed. 
The relevance of bottom trawling in the alteration of natural sediment fluxes over continental shelves has already been pointed out ${ }^{6,25}$, but our results stress that, in addition to altering deep-sea sediment fluxes, bottom trawling also modifies the shape of the upper continental slope, particularly in regions that are strongly affected by this fishing technique. In these portions of the margin, the morphological complexity, as well as benthic habitat heterogeneity, has been drastically reduced, potentially affecting species diversity by regulating levels of competition, predation and physiological stress $^{26}$. Such seascape alteration could also affect ecosystem functioning, because deepsea ecosystems have evolved in these environments to rely upon the original morphological complexity and biogeochemical properties of untrawled surface sediments to support benthic organisms.

This process of seascape spatial levelling has many parallels with landscape evolution under anthropogenic pressures. Changes in land use during the twentieth century resulted in a reduction of landscape diversity almost everywhere through the spreading of arable land and timber plantations, which led to the gradual disappearance of both major and minor elements of topography ${ }^{27}$. Bottom trawling has been compared to forest clear-cutting ${ }^{28}$, although our results suggest that a better comparison might be intensive agricultural activities. Trawled continental-slope environments are the underwater equivalent of a gullied hill slope on land, part of which has been transformed into crop fields that are ploughed regularly, thus replacing the natural contour-normal drainage pattern by levelled areas with a smaller-scale contour-parallel alignment of troughs and crests (Fig. 4, Supplementary Fig. 5). Differences exist in the processes that operate in submarine and subaerial environments. Although farmers usually plough their land a few times per year, at sea trawling can occur on a nearly daily basis (Fig. 3, Supplementary Fig. 1). Also, agricultural activities do not generate the periodic sediment gravity flows that contribute to remove material from fishing grounds. However, the frequent repeated trawling (ploughing) over the same ground, involving displacement of sediments owning to mechanical redistribution, is what ultimately causes the levelling of the surface and produces morphological effects similar to those of a farmer's field.

Warming, sea-level rise, acidification and changes in ocean circulation have been listed as the major present and foreseeable human footprints in the ocean ${ }^{29}$. This work argues for the inclusion in that list of the modification of the submarine landscape 
by trawling, along with the ecological and biogeochemical consequences that may derive from it. Human-induced changes on Earth's geomorphology, already well documented for emerged land ${ }^{30}$, are also present in submerged regions.

\section{METHODS SUMMARY}

This study was conducted using a unique, dedicated experimental strategy combining monitoring of contemporary sediment transport processes, sediment coring, remote operated vehicle (ROV) in situ observations and high-resolution multibeam bathymetric surveys, coupled with the information provided by satellite-based navigation tracks of fishing vessels. Swath bathymetry data from La Fonera (also named Palamós) Canyon were obtained during the EUROLEÓN cruise onboard RV Hespérides in October 2007 using two Simrad multibeam echosounders: EM-1002S in shallow and EM-120 in deep waters. A bathymetric grid of $15-\mathrm{m}$ resolution was generated to obtain the Digital Terrain Model used in this study. Contemporary sediment transport processes were measured by an instrumented mooring line equipped with a downward-looking $300 \mathrm{kHz}$ acoustic Doppler current profiler (ADCP) from Teledyne RDI and three turbidimeters (AQUA logger 520 from the Aquatec Group) deployed from 10 May to 22 September 2011 on the northern flank of La Fonera Canyon, at 980 m depth within the Montgrí tributary valley axis. Seafloor sediment samples from the canyon flanks were collected using a six-tube multicorer from KC-Denmark during the HERMIONE-1 cruise onboard the RV Garcia del Cid. A vertical slab of undisturbed sediment was removed from one of the core tubes for X-ray analysis. A second core tube was sliced at 1-cm intervals for granulometric analyses. Bottom video imagery of La Fonera canyon flanks was recorded in July 2011 during the PROMARES-OASIS DEL MAR research cruise onboard RV Sarmiento de Gamboa by using a high-definition Kongsberg OE14-502A camera mounted on the 2000-m-depth-rated Sub Atlantic Super Mohawk 24 ROV Liropus belonging to the Spanish Institute of Oceanography. The satellite-based tracking of fishing trawlers operating in the study area from the Vessel Monitoring Systems (VMS) data for 2007-2010 was provided by the Fishing Monitoring Centre of the Spanish General Secretariat of Maritime Fishing (SEGEMAR).

Received 20 January; accepted 10 July 2012; doi:10.1038/nature11410. 
1. Thurstan, R. H., Brockington, S. \& Roberts, C. M. The effects of 118 years of industrial fishing on UK bottom trawl fisheries. Nature Commun. 1, 15 (2010).

2. Norse, E. A. et al. Sustainability of deep-sea fisheries. Mar. Policy 36, 307-320 (2012).

3. Watling, L. \& Norse, E. A. Effects of mobile fishing gear on marine benthos. Conserv. Biol. 12, 1178-1179 (1998).

4. Roberts, J. M., Wheeler, A. J. \& Freiwald, A. Reefs of the deep: the biology and geology of cold-water coral ecosystems. Science 312, 543-547 (2006).

5. Jones, J. B. Environmental impact of trawling on the seabed: a review. N. Z. J. Mar. Freshwat. Res. 26, 59-67 (1992).

6. Churchill, J. H. The effect of commercial trawling on sediment resuspension and transport over the Middle Atlantic Bight continental-shelf. Cont. Shelf Res. 9, 841-865 (1989).

7. Schwinghamer, P. et al. Effects of experimental otter trawling on surficial sediment properties of a sandy-bottom ecosystem on the Grand Banks of Newfoundland. Conserv. Biol. 12, 1215-1222 (1998).

8. Brown, E. J., Finney, B., Dommisse, M. \& Hills, S. Effects of commercial otter trawling on the physical environment of the southeastern Bering Sea. Cont. Shelf Res. 25, 1281-1301 (2005).

9. Nittrouer, C. A. \& Wright, L. D. Transport of particles across continental shelves. Rev. Geophys. 32, 85-113 (1994).

10. Pratson, L. F. et al. in Continental-Margin Sedimentation: from Sediment Transport to Sequence Stratigraphy (eds Nittrouer, C. A. et al.) 339-380 (Blackwell, 2007).

11. Piper, D. J. W. \& Normark, W. R. Processes that initiate turbidity currents and their influence on turbidites: a marine geology perspective. J. Sediment. Res. 79, 347-362 (2009).

12. Heezen, B. C., Hollister, C. D. \& Ruddiman, W. F. Shaping of the continental rise by deep geostrophic contour currents. Science 152, 502-508 (1966). 
13. Cacchione, D. A., Pratson, L. F. \& Ogston, A. S. The shaping of continental slopes by internal tides. Science 296, 724-727 (2002).

14. Canals, M. et al. Flushing submarine canyons. Nature 444, 354-357 (2006).

15. Gordon, J. D. M., Bergstad, O. A., Figuereido, I. \& Menezes, G. Deep-water fisheries of the Northeast Atlantic: I. Description and current trends. $J$. Northwest Atlantic Fish. Sci. 31, 137-150 (2003).

16. Morato, T., Watson, R., Pitcher, T. J. \& Pauly, D. Fishing down the deep. Fish Fish. 7, 24-34 (2006).

17. Tobar, R. \& Sardà, F. Análisis de la evolución de las capturas de gamba rosada, Aristeus antennatus (Risso, 1816), en los últimos decenios en Cataluña. Inf. Técn. Inv. Pesq. 142, 3-20 (1987).

18. Martín, J., Puig, P., Palanques, A., Masqué, P. \& García-Orellana, J. Effect of commercial trawling on the deep sedimentation in a Mediterranean submarine canyon. Mar. Geol. 252, 150-155 (2008).

19. Palanques, A. et al. Evidence of sediment gravity flows induced by trawling in the Palamós (Fonera) submarine canyon (northwestern Mediterranean). DeepSea Res. 53, 201-214 (2006).

20. Palanques, A. et al. Suspended sediment fluxes and transport processes in the Gulf of Lions submarine canyons. The role of storms and dense water cascading. Mar. Geol. 234, 43-61 (2006).

21. Lastras, G. et al. Understanding sediment dynamics of two large submarine valleys from seafloor data: Blanes and La Fonera canyons, northwestern Mediterranean Sea. Mar. Geol. 280, 20-39 (2011).

22. Halpern, B. S. et al. A global map of human impact on marine ecosystems. Science 319, 948-952 (2008).

23. Benn, A. R. et al. Human activities on the deep seafloor in the North East Atlantic: an assessment of spatial extent. PLoS ONE 5, e12730 (2010).

24. Crutzen, P. J. Geology of mankind. Nature 415, 23 (2002).

25. Ferré, B., Durrieu de Madron, X., Estournel, C., Ulses, C. \& Le Corre, G. Impact of natural (waves and currents) and anthropogenic (trawl) resuspension 
on the export of particulate matter to the open ocean: application to the Gulf of Lion (NW Mediterranean). Cont. Shelf Res. 28, 2071-2091 (2008).

26. Levin, L. A., Sibuet, M., Gooday, A. J., Smith, C. R. \& Vanreusel, A. The roles of habitat heterogeneity in generating and maintaining biodiversity on continental margins: an introduction. Mar. Ecol. 31, 1-5 (2010).

27. Csorba, P. in Anthropogenic Geomorphology (eds Szabó, J., Dávid, L. \& Dénes, L.) 39-52 (Springer, 2010).

28. Watling, L. \& Norse, E. A. Disturbance of the seabed by mobile fishing gear: a comparison with forest clear-cutting. Conserv. Biol. 12, 1180-1197 (1998).

29. Tyrrell, T. Anthropogenic modification of the oceans. Phil. Trans. R. Soc. Lond. A 369, 887-908 (2011).

30. Price, S. J., Ford, J. R., Cooper, A. H. \& Neal, C. Humans as major geological and geomorphological agents in the Anthropocene: the significance of artificial ground in Great Britain. Phil. Trans. R. Soc. A 369, 1056-1084 (2011). </jrn>

Supplementary Information is available in the online version of the paper.

Acknowledgements This work was supported by various research projects: HERMIONE (226354 and CTM2010-11084-E), DOS MARES (CTM2010-21810-C03), OASIS DEL MAR - Obra Social "la Caixa”, GRACCIE-CONSOLIDER (CSD2007-00067) and REDECO (CTM2008-04973-E). We also received support from Catalan Government Grups de Recerca Consolidats grants (2009 SGR 899 and 1305). VMS data and support were provided by the Spanish General Secretariat of Maritime Fishing (SEGEMAR). Assistance at sea by the crews of RV Hespérides, RV Sarmiento de Gamboa and RV García del Cid is also acknowledged. J.M. was funded through a JAE-DOC contract granted by Consejo Superior de Investigaciones Científicas and co-financed by the European Social Fund. F. Sardà and T. Milligan provided comments on the manuscript. The final document benefited from a review by $\mathrm{P}$. Talling.

Author Contributions All authors contributed to the design and implementation of the experimental strategy. P.P., M.C. and J.B.C. steered the integration and joint analysis of the data. P.P. and J.M. drafted the manuscript, which was critically revised and implemented by M.C. and J.B.C. M.C. designed and coordinated the acquisition of seafloor data, including multibeam bathymetry and ROV observations, and obtained VMS data. P.P., J.M. and A.P. acquired and processed the mooring time series and the sediment cores. J.M. and J.B.C. conducted the bibliographical survey of global slope fishing grounds. D.A., M.C. and P.P. produced the various maps in the paper, to which J.M and J.B.C. contributed. G.L. coordinated the multibeam bathymetry processing and, jointly with M.C., created the slope failures table. J.B.C. 
provided knowledge about local fishing activities. M.C., D.A., G.L. and A.M.C. described and interpreted the whole set of seafloor data. All authors discussed the results and commented on the final version of the manuscript.

Author Information Reprints and permissions information is available at www.nature.com/reprints. The authors declare no competing financial interests. Readers are welcome to comment on the online version of the paper. Correspondence and requests for materials should be addressed to P.P. (ppuig@icm.csic.es).

Figure 1 | Map of known trawling grounds on the world continental slopes. Red areas illustrate the extent of the trawling and the letters refer to the main fishery operating in each area, as detailed in the Supplementary Information. Darker blue regions represent water depths exceeding $2,000 \mathrm{~m}$.

Figure 2 | Bathymetric map of the study area. Bathymetric map of the northern Catalan margin (northwestern Mediterranean) showing the main trawling grounds on the open continental slope and canyon flanks (blue hatching). Data was obtained from the VMS. The largest ports of the area (vessels in white circles) and the 800-m isobath (white thick contour) are highlighted. The location of Fig. 4 and the mooring station (red star in white box; see Fig. 3 and Supplementary Fig. 1) in La Fonera (also named Palamós) Canyon are indicated.

\section{Figure 3 | Time series observations of trawling-induced sediment gravity flows.}

Graphs showing near-bottom suspended sediment concentration (SSC) and current speed records observed at the northern flank of La Fonera Canyon during a two-week period at different heights above the sea floor (m.a.s.f., metres above sea floor).

Sediment transport events were observed during weekdays (that is, working days for the fishery), but not on weekends. The detail of a one-day record (21 June 2011) shows two sharp increases in SSC and the consequent intensification of the current speed (directed downslope towards $192^{\circ}$ ), with higher velocities closer to the sea floor that denote the occurrence of sediment gravity flows. The two peaks correspond to the two main hauls of the trawling fleet, the first one heading offshore and the second one heading to port. Orange bars on the $x$ axes denote working days and working hours, respectively. Note the change in scale of the current-speed $y$ axes. See mooring location in Figs 2 and 4 and Supplementary Figs 2 and 3.

Figure 4 | Seafloor morphology and bottom trawling in La Fonera Canyon. a, Shaded relief image from a $15-\mathrm{m}$ resolution bathymetric grid showing gullied and 
smoothed seafloor regions, the latter at depths shallower than $800 \mathrm{~m}$ (white contour) especially on the northern flank but also in parts of the southern flank. b, Positioning data (small yellow arrows) of bottom trawling vessels fishing from 2007 to 2010. c, Slope map illustrating regions of homogeneous values between $10^{\circ}$ and $30^{\circ}$ in the most heavily trawled regions of the canyon flanks compared to untrawled regions where the gullied sea floor and the tributary valley networks are apparent, displaying higher $\left(>40^{\circ}\right)$ and lower $\left(<10^{\circ}\right)$ slopes in the walls and axes of the various valleys, respectively. The positions of the mooring station (red star; see Fig. 3 and Supplementary Fig. 1), sediment cores (green dots; see Supplementary Fig. 4) and ROV images (green triangles; see Supplementary Fig. 5) are also indicated.

\section{METHODS}

\section{Time series observations}

An instrumented mooring line equipped with a downward-looking $300 \mathrm{kHz}$ acoustic Doppler current profiler (ADCP) from Teledyne RDI placed at $82 \mathrm{~m}$ above sea floor (m.a.s.f.) and three Seapoint turbidimeters (AQUA logger 520 from the Aquatec Group) placed at 5, 20 and 50 m.a.s.f., was deployed from 10 May to 22 September 2011 in the axis of the Montgrí tributary valley on the northern flank of La Fonera Canyon $\left(41^{\circ} 52.49^{\prime} \mathrm{N} ; 3^{\circ} 20.66^{\prime} \mathrm{E}\right)$, at $980 \mathrm{~m}$ water depth, slightly deeper than the maximum trawling depth (see position in Figs 2 and 4). Turbidimeters were programmed to measure Formazin Turbidity Units (FTU) at 1-min sampling intervals in auto-gain mode, and FTU readings were converted to estimates of suspended sediment concentration (SSC) according to ref. 31 using standard methods. The ADCP was programmed to sample at 5-min intervals with 60 pings per ensemble at minimum time

ping (standard deviation $0.9 \mathrm{~cm} \mathrm{~s}^{-1}$ ) and a depth cell size of $2 \mathrm{~m}$, and recorded data until 23 September 2011. Owing to acoustic interference with the steep sea floor, the lowest cell (that is, the one closest to the bottom) with reliable current data was at 12 m.a.s.f. and the highest cell was at 80 m.a.s.f.

\section{Sediment fluxes}

To estimate the down-slope sediment transport at the mooring location, the north and east current components from each ADCP cell were transformed to along-valley and across-valley current components, using an $11^{\circ}$ clockwise rotation from north as the orientation of the tributary valley axis. Downslope sediment fluxes were then obtained by multiplying the along-valley current velocity from each ADCP cell by the estimate 
of SSC at the same depth level, obtained from a linear regression between SSC measurements from 5 to 20 m.a.s.f., and from 20 to 50 m.a.s.f., averaged at 5-min intervals. Currents from 12 m.a.s.f. were assumed to be the same down to 4 m.a.s.f. to calculate near-bottom fluxes, considering SSC measurements from 5 m.a.s.f. and the currents from 4 to 6 m.a.s.f. to be the lowest cell. The time-integrated cumulative transport through each cell, computed as tonnes per square metre, was multiplied by its height (that is, $2 \mathrm{~m}$ ) and the valley width at the water depth of the cell to obtain the mass of sediment that passed through the various levels (that is, from 4 to 50 m.a.s.f.). The integration of the transport at all levels gave an estimate of the amount of sediment that was exported downslope through the tributary valley during the observational period (136 days). This value should be considered a minimum estimate, because the flux above 50 m.a.s.f. and, more importantly, the flux from 4 m.a.s.f. to the sea floor, where most of the sediment transport probably occurs, could not be accurately calculated.

\section{Multibeam bathymetry}

Swath bathymetry data were obtained during the EUROLEÓN cruise onboard RV Hespérides in October 2007 using two Simrad multibeam echosounders: an EM-1002S for shallow depths and an EM-120 in deep waters. The EM-1002S works at a frequency of $95 \mathrm{kHz}$ with 111 beams per ping, whereas the EM-120 works at a frequency of $12 \mathrm{kHz}$ with 191 beams per ping. Both were operated in equidistant mode, with swath width independent of water depth and fixed to $500 \mathrm{~m}$. Data were logged using Kongsberg's Seafloor Information System (SIS). Processing of both multibeam data sets was conducted using Caris HIPS and SIPS software (http://www.caris.com/products/hips-sips/) and included corrections for ship motion, sound speed and spurious data. A bathymetric grid of $15-\mathrm{m}$ resolution was generated to obtain the final Digital Terrain Model and slope gradient map illustrated in Fig. 4, and a 50-m bathymetric grid subsample was used to perform the rugosity analysis shown in Supplementary Fig. 2.

\section{Trawlers' satellite-based tracking}

Within the framework of the Common Fisheries Policy of the European Union, the Fishing Monitoring Centre of the Spanish General Secretariat of Maritime Fishing (SEGEMAR) continuously tracks about 1,400 fishing vessels equipped with and operating satellite-based Vessel Monitoring Systems (VMS) ${ }^{32}$, commonly referred to as 'blue boxes'. Blue boxes are standardized, protected and sealed against power cuts, the 
marine environment and to prevent any manipulation. Each blue box consists of a positioning unit and a satellite-based transmission-reception station, along with data logging and storage devices. VMS uses the Global Positioning System and Inmarsat-C for positioning and data transmission, respectively. Data are stored in the VMS internal memory during six months. Blue boxes also have supplementary buttons with which to select the vessel's activity at any time. The VMS provides information on a vessel's position, direction and speed and is able to determine each vessel's activity (that is, fishing, sailing, drifting or docked) at any time regardless of whether it is located in authorized or prohibited waters. The error margin in the positioning is less than $100 \mathrm{~m}$ and the maximum time between the transmission of a message and its reception at the Fishing Monitoring Centre is $10 \mathrm{~min}$. The route followed by each vessel is known and its speed reveals whether it is sailing or fishing. For the blue and red deep-sea shrimp Aristeus antennatus fishery, sustained vessel speeds of less than 3.5 knots imply that the vessel is fishing. The VMS information represented in Fig. 4b corresponds to 55 different VMS identification codes (that is, vessels) for the period extending from 1 January 2007 to 31 December 2010. The VMS information in Fig. 4b was filtered by depth and speed. Vessel velocities higher than 3.5 knots and depths shallower than $130 \mathrm{~m}$ (that is, the mean depth of the continental shelf edge in the study area) were removed to illustrate better the actual fishing activity in slope waters. Each vessel heading has also been illustrated in Fig. $4 \mathrm{~b}$ by means of small, course-oriented arrows.

\section{Bottom sediment samples}

Seafloor sediment samples were collected in La Fonera Canyon using a six-tube KCDenmark multicorer during the HERMIONE-1 cruise onboard the RV García del Cid. A vertical slab of undisturbed sediment was removed from one of the core tubes for Xradiographic analysis. A second core tube was sliced at $1 \mathrm{~cm}$ intervals for further analyses. Dry bulk density was determined as the ratio of freeze-dried weight to volume of wet sediment slice. For granulometric analysis, about $1 \mathrm{~g}$ of lyophilized sediment sample was treated with $20 \% \mathrm{H}_{2} \mathrm{O}_{2}$ to remove organic matter and then dispersed by adding sodium polyphosphate solution. Grain size analysis of the prepared sample was conducted by laser diffraction using a Horiba Partica LA-950V2 particle-size analyser. The LA-950V2 detects particles in the range $0.01-3,000 \mu \mathrm{m}$, so sediment samples were sieved through a 2,000- $\mu \mathrm{m}$ mess screen before analysis and the grain size distribution obtained by laser diffraction was corrected to include the relative percentage of gravel. 


\section{Remote operated vehicle imagery}

Bottom video imagery of trawled and untrawled sections of La Fonera canyon flanks was recorded in July 2011 during the PROMARES-OASIS DEL MAR research cruise onboard the Spanish RV Sarmiento de Gamboa by using a high-definition Kongsberg OE14-502A camera mounted on the 2,000-m-depth-rated Sub Atlantic Super Mohawk 24 ROV Liropus belonging to the Spanish Institute of Oceanography. Single frames were subsequently extracted from the video records using Videolan (VLC version 1.1.11 The Luggage) and Avidemux (version 2.5.4) media player software. Underwater positioning was ensured by a high-precision HiPAP 350P acoustic system linked to the DGPS positioning system of the vessel. Position accuracy of the HiPAP $350 \mathrm{P}$ is $0.3 \%$ of the range and its range detection accuracy is less than $20 \mathrm{~cm}$.

31. Guillén, J., Palanques, A., Puig, P., Durrieu de Madron, X. \& Nyffeler, F. Field calibration of optical sensors for measuring suspended sediment concentration in the western Mediterranean. Sci. Mar. 64, 427-435 (2000).

32. Commission Regulation (EC) No. 2244/2003 of 18 December 2003 laying down detailed provisions regarding satellite-based Vessel Monitoring Systems.

Official J. Eur. Union L333, 17-27 (2003); http://eurlex.europa.eu/LexUriServ/LexUriServ.do?uri=OJ:L:2003:333:0017:0027:EN:P DF. 


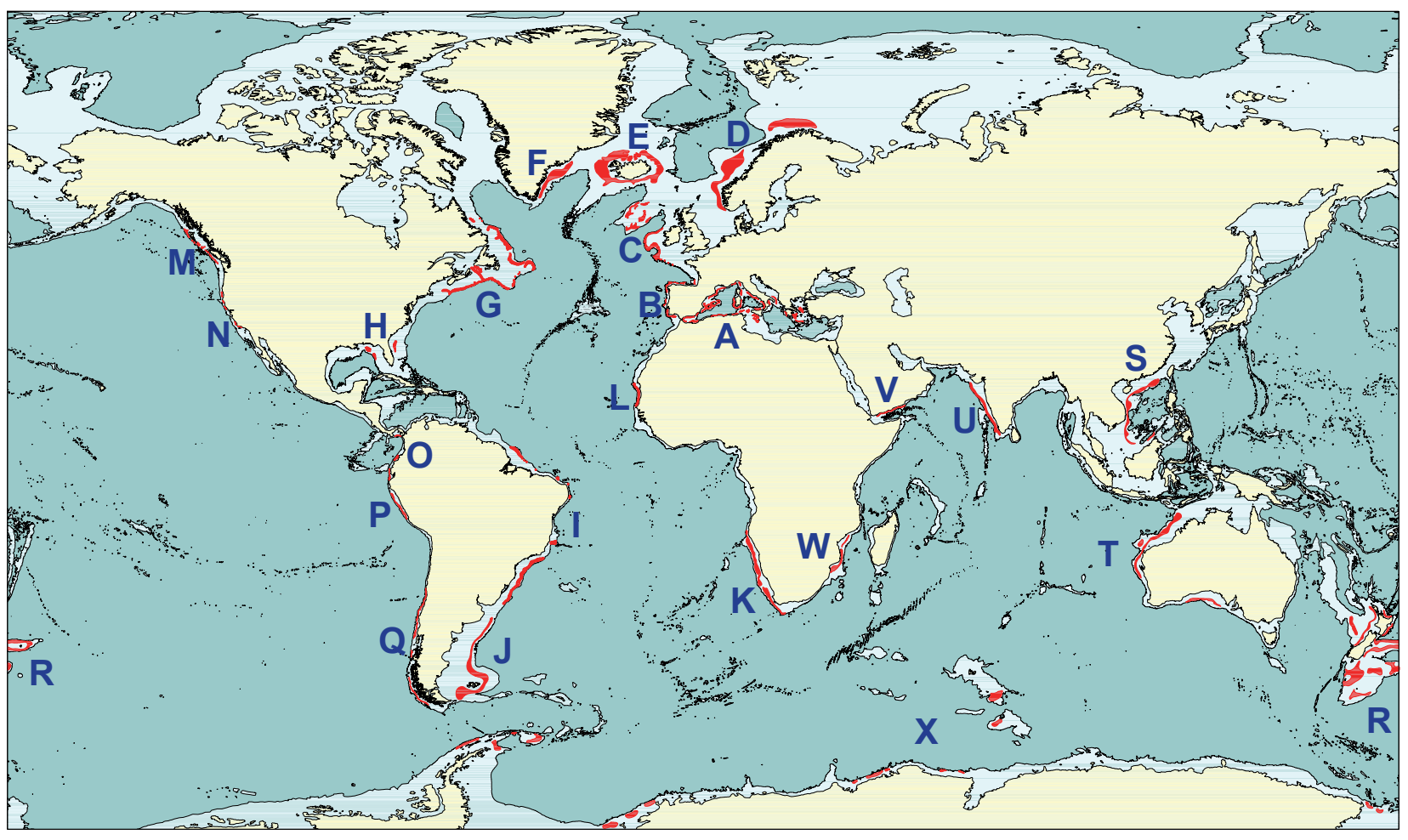




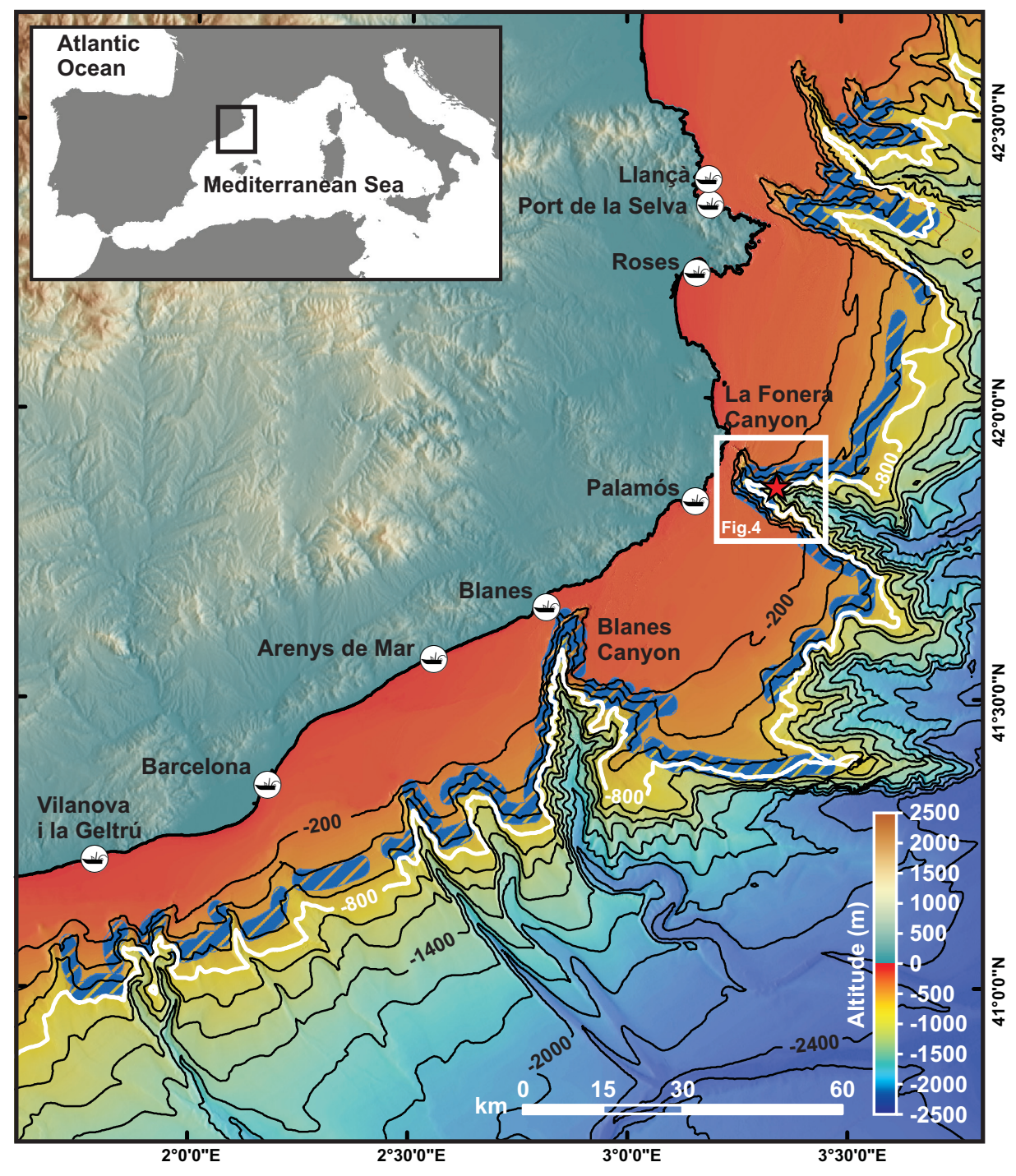



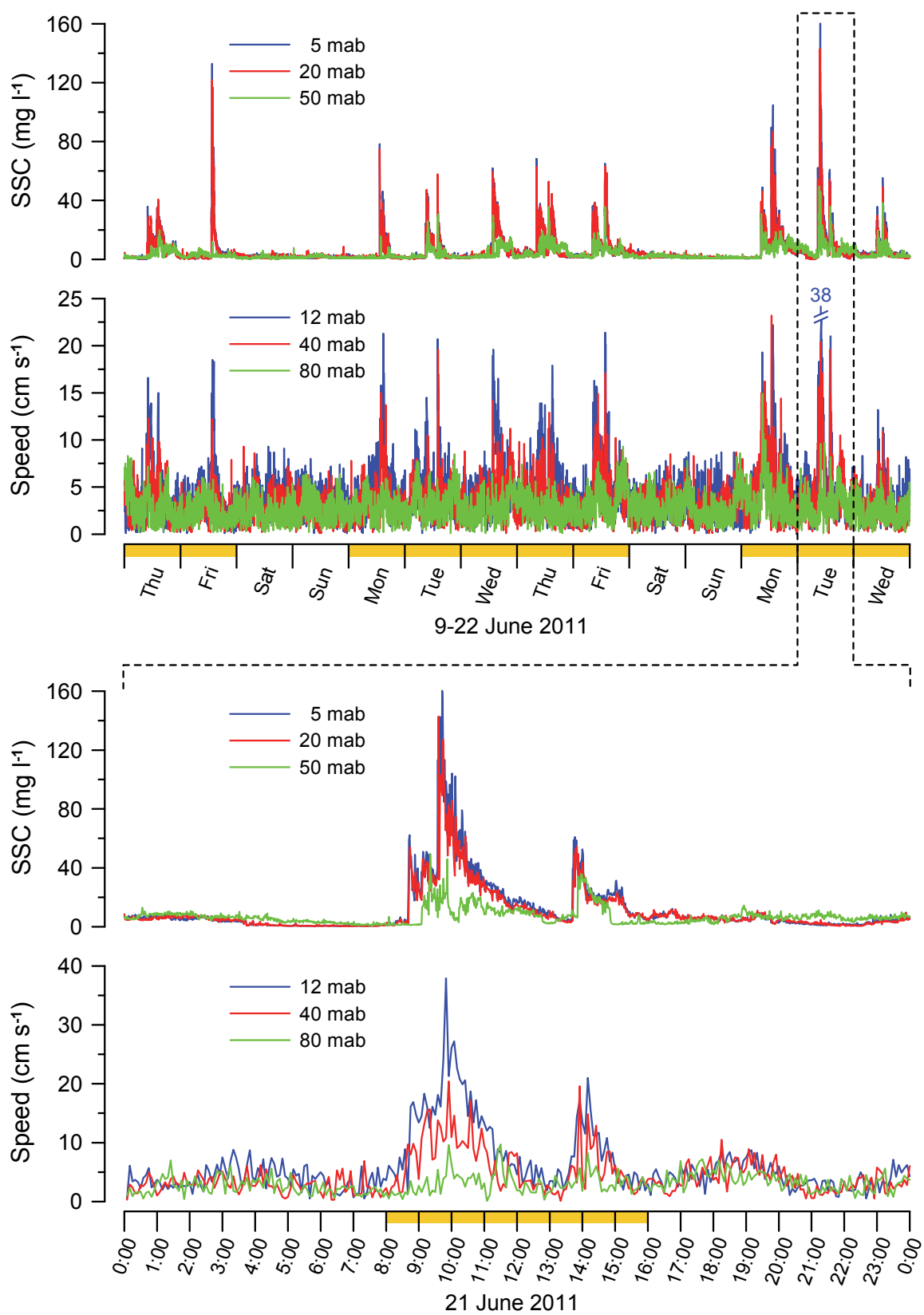


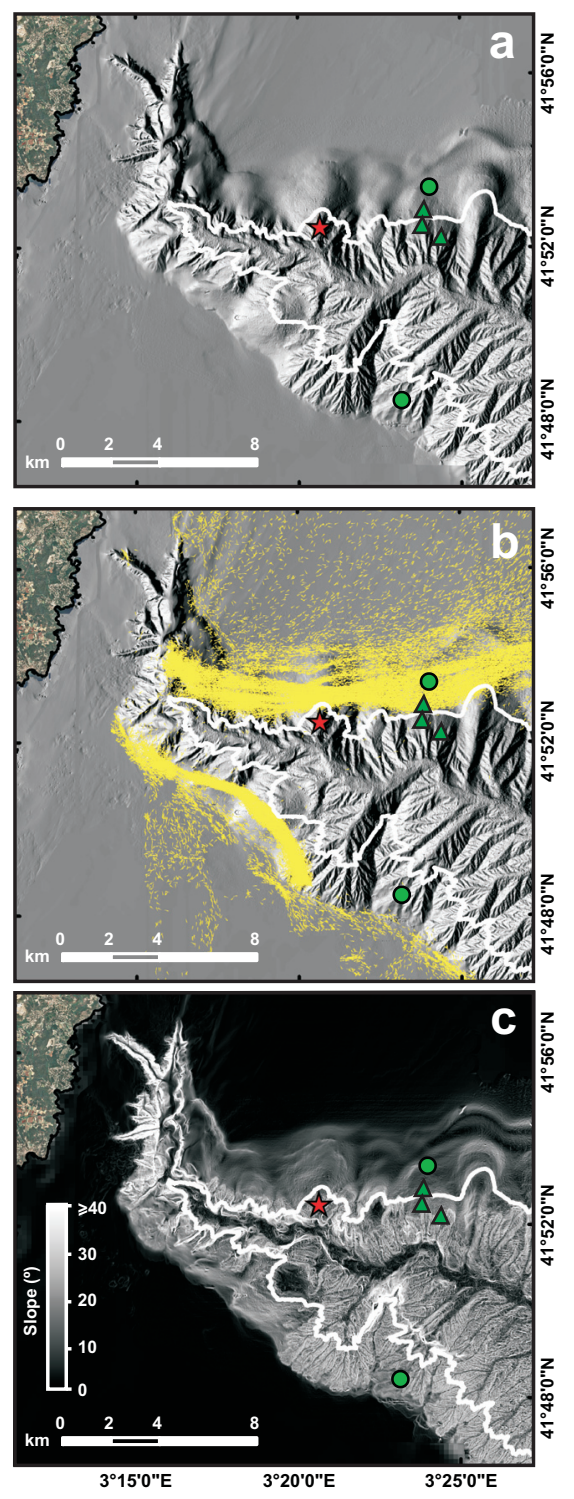

